\title{
Medicated chewing gum: An unconventional drug delivery system
}

\author{
Sabera Khatun, *Kumar Bishwajit Sutradhar \\ Department of Pharmacy, Stamford University Bangladesh, 51 Siddeswari Road, Dhaka 1209, Bangladesh
}

\begin{abstract}
Medicated chewing gum has a history for about a century. Now-a-days it is considered to be a potential and convenient modified release drug delivery system which can be used in pain relief medication, smoking cessation, travel illness, freshening of breath, prevention of dental caries, alleviation of xerostomia, vitamin or mineral supplementation etc. Medicated chewing gums are prepared by using a water insoluble gum base with water soluble bulk portion. This formulation offers both local and systemic effects and has a range of advantages over conventional oral solid dosage forms. USP currently has no in vitro release testing apparatus for the evaluation and determination of drug release from the prepared chewing gums. But European Pharmacopoeia adopted a compendial apparatus to do so. Medicated chewing has drawn attention to the researchers as potential drug delivery system and it could be a commercial success in near future.
\end{abstract}

Key Words: pharmaceutical chewing gum, gum base, oral mucosal drug delivery, buccal membrane, apparatus.

\section{INTRODUCTION}

The first medicated chewing gum was introduced in the USA in 1924 with the brand name Aspergum ${ }^{\circledR}$ (Imfeld, 1999). But history suggests that chewing of non-food items for the purpose of pleasure is as old as ancient Egyptian, Mayan civilizations. In 1848, the first commercial chewing gum named State of Maine Pure Spruce Gum appeared in the market whereas the first patent was issued to Dr. W.F. Semple who was a dentist at Ohio in 1869. Many people chew gum partly due to the belief that it increases aspects of mental performance, including concentration (Wilkinson et al., 2002). In a study published by Al-Haboubi et al. in 2010 concluded that regular use of sugar-free chewing gum is associated with certain clinical and self-perceived benefits in older people living in the community. Scholey et al. 2009 found that the chewing of gum was associated with a small overall increase in performance on a battery of cognitive tests. Other studies indicate that chewing gum offers a range of benefits (Onyper et al., 2011) like verbal working

\footnotetext{
*Corresponding Author:

Kumar Bishwajit Sutradhar, Lecturer

Department of Pharmacy

Stamford University Bangladesh

Dhaka-1217, Bangladesh

E-mail: kumarbishwajit.pharm@gmail.com

Contact No.: +8801911089806
}

memory (Hirano et al., 2008; Zoladz and Raudenbush, 2005), free recall (Baker et al., 2004; Johnson \& Miles, 2008), attention (Smith, 2010; Tucha et al., 2004; Tucha \& Simpson, 2011), as well as performance on reaction time measures (Sakamotoet et al., 2009; Smith, 2010).

As chewing gums are taken orally and oral route of drug delivery is the most preferred route amongst the patient and clinicians due to various advantages it offers (Shojaei, 1998), in recent years chewing gums are considered to be friendly oral mucosal drug delivery systems (Surana, 2010). Chewing gum has been used to deliver therapeutic agents such as nicotine for smoking cessation therapy (Batra et al., 2005; Moore et al., 2008). A medicated chewing gum is solid, single-dose preparation that is intended to be chewed for a certain period of time, deliver the drug and which may contain one or more than one active pharmaceutical ingredient (Mehta et al., 2010). Chewing gums are not swallowed and the remaining mass after chewing is discarded. During chewing the drug contained in the gum is released into the saliva. The released drug has got two fates; either it could be absorbed through the oral mucosa or may reach the stomach for GI absorption. In fact both these two fates may occur simultaneously. So, medicated chewing gums offer both local and systemic effect. This drug delivery system offers two 
Table 1: Limitations of conventional/traditional method and freezing, grinding \& tableting method of chewing gum preparation (Heema and Stuti, 2010).

\begin{tabular}{ll}
\hline Manufacturing method & Limitation \\
\hline Conventional/ traditional method & $\begin{array}{l}\text { Manufacturing of thermolabile may become challenging as } \\
\text { elevated temperature is required during melting; }\end{array}$ \\
& If the gum is highly viscous, accurate dosing is not possible; \\
& Lack of precise form, shape, weight of dosage form; \\
Grinding and compression: difficult to formulate chewing & gum as tablets due to high moisture content. \\
\hline Freezing, grinding and tableting method & $\begin{array}{l}\text { High-tech, expensive equipments are required; } \\
\text { Careful monitoring of humidity during manufacturing } \\
\text { process becomes a challenge. }\end{array}$ \\
\hline
\end{tabular}

absorption pathways. Drug absorbed directly via the buccal membrane avoids metabolism in the gastrointestinal tract and thus the chance of first pass effect of the liver. As a result drug formulation as medicated chewing gum may require reduced dose compared to other oral drug delivery systems.

This review will focus on different aspects of medicated chewing gum including advantages of the dosage form over other oral solid dosage forms, manufacturing methods, methods for evaluation, therapeutic applications.

\section{BENEFITS}

Medicated chewing gums offer a range of advantages as identified by the classic review work of Imfeld in 1999. The advantages may be summarized as bellow:

- Chewing gum can be used without water, at any time, and everywhere.

- As the incorporated therapeutic agents are protected from oxygen, light, and water, product stability is good.

- Chewing gum can produce both local effects in the mouth (local delivery) and systemic effects after the active agents have been swallowed or (preferably) after they have been absorbed through the oral mucosa. The later is of special interest with respect to bioavailability, since it avoids metabolism of the drug in the gastrointestinal tract and the so called liver-first-pass effect, because oral veins drain into the vena cava.
The other benefits that chewing gum may offer as a pharmaceutical dosage form are (Rassing, 1996; Surana, 2010; Heema and Stuti, 2010):

1. Fast/rapid onset of action

2. High bioavailability

3. Pleasant taste

4. Ready for use

5. High acceptance by children and for patients who find swallowing tablets difficult

6. Fewer side effects

7. Effect on dry mouth (xerostomia)

8. Product distinctiveness from a marketing perspective

9. Excellent for acute medication

10. Aspirin, Dimenhydrinate and Caffeine shows faster absorption through MCG than tablets.

\section{MANUFACTURING AND EVALUATION}

Medicated chewing gums can be manufactured by various techniques and methods. There are three major manufacturing methods available for medicated chewing gum formulation; 1) Conventional/ traditional method (melting) (Athanikar and Gubler, 2001), 2) freezing, grinding and tabletting method (Athanikar and Gubler, 2001; Keizo and Fumio, 1976) and 3) direct compression method (Heema and Stuti, 2010). Chewing gum prepared by using directly compressible chewing gum excipients like PharmaGum S, M and C offers formulation of a chewing gum which delivers drug more quickly and can be prepared in a more cost effective manner. The other two methods have got some limitations as described in Table 1. 
Table 2: Components required for medicated chewing gum formulation.

\begin{tabular}{|c|c|c|}
\hline Component & Function & Example \\
\hline \multicolumn{3}{|l|}{ Water insoluble gum base } \\
\hline Elastomers & $\begin{array}{l}\text { Provides elasticity and } \\
\text { controls gummy texture }\end{array}$ & $\begin{array}{l}\text { Natural (chicle gum, nispero, rosadinha, jelutong, } \\
\text { periollo, lechi-capsi, sorva etc.) and synthetic rub- } \\
\text { bers (butadiene, styrene copolymers, } \\
\text { polyisobutylene, polyethylene mixtures, polyvinyl } \\
\text { alcohol etc.) }\end{array}$ \\
\hline Elastomer solvents & $\begin{array}{l}\text { Softening the elastomer base } \\
\text { component }\end{array}$ & $\begin{array}{l}\text { Terpinene resins (polymers of alpha-pinene or beta- } \\
\text { pinene), modified resins or gums (hydrogenated, } \\
\text { dimerized or polymerized resins) }\end{array}$ \\
\hline Plastisizers & $\begin{array}{l}\text { To obtain a variety of desirable } \\
\text { textures and consistency proper- } \\
\text { ties }\end{array}$ & $\begin{array}{l}\text { Lanolin, palmitic acid, oleic acid, stearic acid, gly- } \\
\text { ceryl triacetate, propylene glycol monostearate, } \\
\text { glycerine, natural and synthetic waxes, hydroge- } \\
\text { nated vegetable oils, paraffin waxes, fatty waxes, } \\
\text { sorbital monostearate, propylene glycol }\end{array}$ \\
\hline $\begin{array}{l}\text { Fillers or texturizers or } \\
\text { mineral adjuvant }\end{array}$ & $\begin{array}{l}\text { Provide texture, improve chewa- } \\
\text { bility, provide reasonable size of } \\
\text { the gum lump with low dose } \\
\text { drug }\end{array}$ & $\begin{array}{l}\text { Calcium carbonate, magnesium carbonate, alumi- } \\
\text { num hydroxide, talc, aluminum silicate }\end{array}$ \\
\hline \multicolumn{3}{|l|}{ Water soluble portions } \\
\hline Softners and emulsifiers & $\begin{array}{l}\text { These are added to the chewing } \\
\text { gum in order to optimize the } \\
\text { chewability and mouth feel of the } \\
\text { gum }\end{array}$ & $\begin{array}{l}\text { Glycerin, lecithin, tallow, hydrogenated tallow, } \\
\text { mono/ di/ tri glycerides }\end{array}$ \\
\hline Colorants and whiteners & $\begin{array}{l}\text { Gives the formulation soothing } \\
\text { color and improves acceptability } \\
\text { of the formulation }\end{array}$ & $\begin{array}{l}\text { Titanium dioxide, natural food colors and dyes suit- } \\
\text { able for food, drug and cosmetic applications }\end{array}$ \\
\hline Sweeteners & $\begin{array}{l}\text { To provide the desired sweetness } \\
\text { of the product }\end{array}$ & $\begin{array}{l}\text { Water soluble sweetening agents (xylose, ribulose, } \\
\text { glucose, mannose, galactose, sucrose, fructose, mal- } \\
\text { tose, monellin, sugar alcohols like sorbitol, mannitol } \\
\text { etc.), water soluble artificial sweeteners (sodium or } \\
\text { calcium saccharin salts, cyclamate salts etc.), di- } \\
\text { peptide based sweeteners (aspartame, alitame etc.), } \\
\text { naturally occurring water soluble sweeteners, chlo- } \\
\text { rinated derivatives of ordinary sugar (sucralose), } \\
\text { protein based sweeteners (thaumatin I and II) }\end{array}$ \\
\hline Antioxidants & $\begin{array}{l}\text { Prevents any possible microbial } \\
\text { growth }\end{array}$ & $\begin{array}{l}\text { Butylated hydroxytoluene, butylated hydroxyani- } \\
\text { sole, propyl gallate }\end{array}$ \\
\hline Flavoring agents & $\begin{array}{l}\text { To enhance consumer acceptabili- } \\
\text { ty }\end{array}$ & $\begin{array}{l}\text { Essential oils (citrus oil, fruit essences, peppermint } \\
\text { oil, spearmint oil, mint oil, clove oil and oil of win- } \\
\text { tergreen) and synthetic or artificial flavors }\end{array}$ \\
\hline Bulking agents & Used if low calorie gum is desired & $\begin{array}{l}\text { Polydextrose, oligofructose, inulin, fructooligosac- } \\
\text { charides, guargum hydrolysate, indigestible dextrin }\end{array}$ \\
\hline Compression adjuvant & To ease the compression process & $\begin{array}{l}\text { Silicon dioxide, magnesium stearate, calcium stea- } \\
\text { rate, talc }\end{array}$ \\
\hline
\end{tabular}

\section{Composition}

The most important material in chewing gum formulation apart from the active ingredient is the gum base which is an inert and insoluble no-nutritive component. The other materials may be grouped as water soluble bulk portion (Zyck et al., 2003). Table 2 summarizes the basic components required for the manufacturing of medicated chewing gum with 


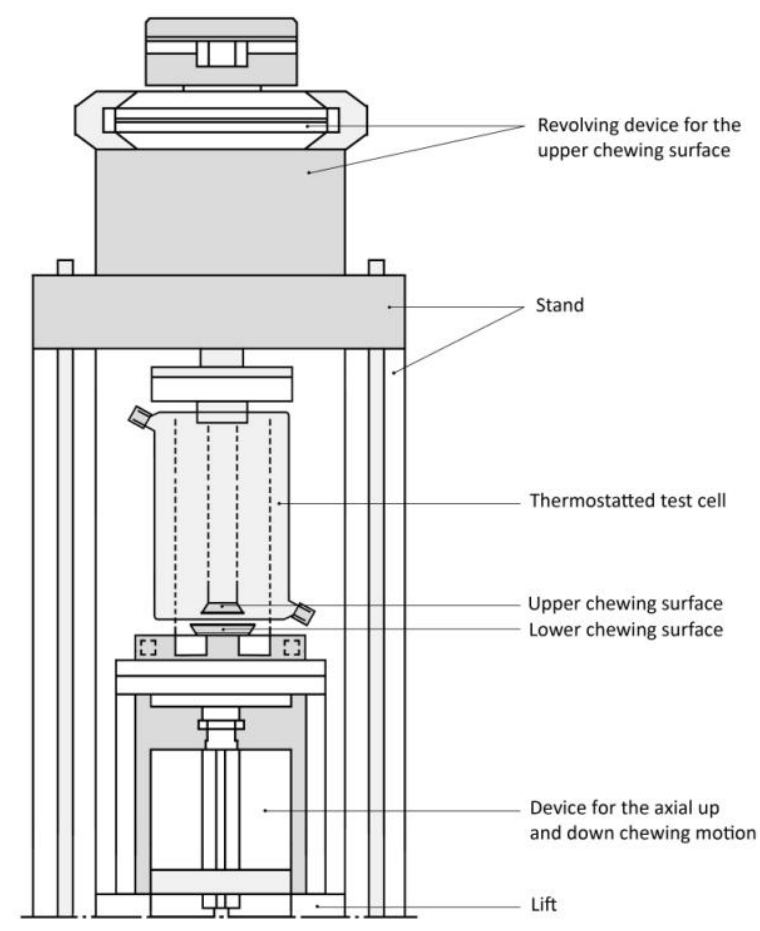

Figure 1: Schematic diagram of chewing apparatus for in vitro drug release study from medicated chewing gum (adopted from Gajendran et al., 2008).

their function and suitable examples (Bhise and Jahagirdar, 2005; Heema and Stuti, 2010).

\section{Evaluation}

Product quality tests for medicated chewing gums are described by Gajendran et al. (2008) according to European Pharmacopoeia. The tests include assay, identification and uniformity of dosage units, content, and mass. In addition to product quality tests several additional tests are done which are specific to the product and these tests ensure that the finished product is of quality as desired by the manufacturer. The tests generally include: texture analysis, product feel and consistency, evaluation of flavors and sweeteners, tests for coatings, impurities, water content, degradation products, residual solvents, etc. As USP does not contain a compendial apparatus for performance testing of medicated chewing gums in many cases product performance data are generated by apparatus developed by the drug product manufacturers and is not contained in the public monograph.

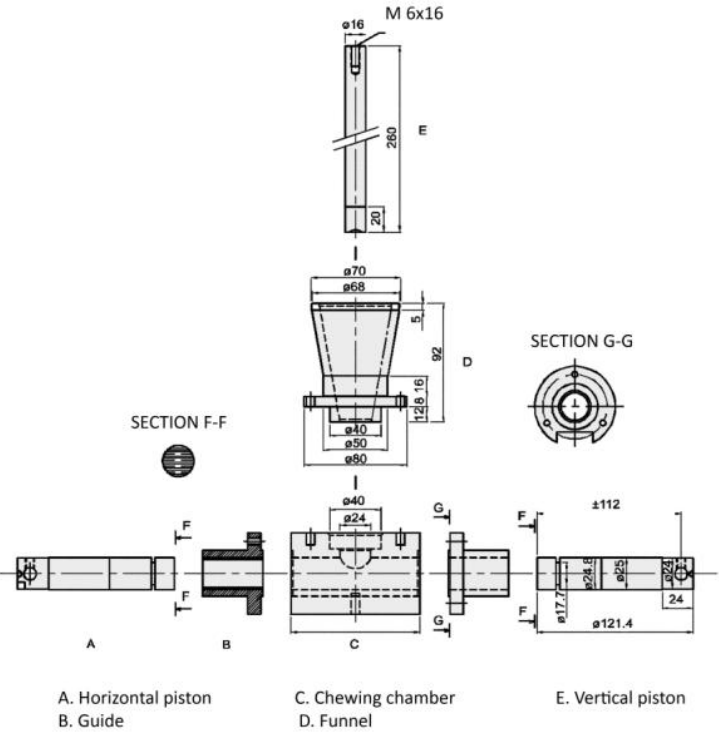

Figure 2: Schematic diagram of single-module chewing apparatus for in vitro drug release study from medicated chewing gum (adopted from Gajendran et al., 2008).

To study in vitro drug release from the medicated chewing gum European Pharmacopoeia adopted an apparatus; Apparatus I. Chewing Gum Apparatus, Compendial-Ph. Eur in 2000 (European Directorate for the Quality of Medicines, Council of Europe, European Pharmacopoeia, 2000). Apparatus II, Alternative Chewing Gum Apparatus, Noncompendial-Wennergren is one of the noncompendial apparatus commercially available which was designed by Wennergren (Kvist et al., 1999). Schematic diagram of apparatus for determination of drug release and single-module chewing apparatus (apparatus II) for in vitro drug releases study of medicated chewing gum are presented in Figure 1 and Figure 2 respectively.

\section{THERAPEUTIC APPLICATION}

Medicated chewing gums are used in various therapeutic purposes. A brief list of the therapeutic uses of medicated chewing gums is given in Table 3 .

\section{CONCLUSION}

Medicated chewing gums could be a great way of delivering drug to the body either for local or systemic effect. The preparation procedure is easy and the dosage form is convenient to use, has got great 
Table 3: Therapeutic uses of medicated chewing gums.

\begin{tabular}{|c|c|c|}
\hline Therapeutic use & Specific example & Reference \\
\hline Oral antifungal & $\begin{array}{l}\text { Econazole } \\
\text { Nystatine } \\
\text { Miconazole }\end{array}$ & $\begin{array}{l}\text { Jacobsen } \text { et al., } 1999 \\
\text { Andersen } \text { et al., } 1990 \\
\text { Pedersen and Rassing, 1990a; Jacobsen et al., 1999; Peder- } \\
\text { sen and Rassing, 1990b; Pedersen and Rassing, 1991; } \\
\text { Rindum et al., 1993; Bastian et al., } 2004\end{array}$ \\
\hline Smoking cessation & $\begin{array}{l}\text { Nicotine } \\
\text { Silver acetate }\end{array}$ & $\begin{array}{l}\text { Jensen et al., 1990; Jensen et al., 1991; Peters and Morgan, } \\
\text { 2002; Morjaria et al., } 2004 \\
\text { Malcolm et al., 1986; Jensen et al., 1990; Jensen et al., } 1991\end{array}$ \\
\hline Pain relievers & $\begin{array}{l}\text { Aspirin } \\
\text { Methadone }\end{array}$ & $\begin{array}{l}\text { Bousquet et al., 1992; Christrup and Rassing, } 1988 \\
\text { Hodoba, } 1999\end{array}$ \\
\hline $\begin{array}{l}\text { CNS stimulation, improvement of } \\
\text { memory }\end{array}$ & Caffeine & Kamimori et al., 2002 \\
\hline Treatment of otitis media & Xylitol & Uhari et al., 1998; Skofitsch and Lembeck, 1983 \\
\hline Treatment of dental carries & Chlorhexidine & Imfeld, 2006 \\
\hline Treatment of vitamin C deficiency & & Christrup et al., 1988; Heema and Stuti, 2010 \\
\hline $\begin{array}{l}\text { Treatment and management of mo- } \\
\text { tion sickness }\end{array}$ & Dimenhydrinate & Seibel et al., 2002 \\
\hline Acid neutralization & Antacid & Bhise and Jahagirdar, 2005 \\
\hline
\end{tabular}

patient compliance. The mouth freshening effect also adds some advantages. But quality testing procedures are not still well developed. The USP does not have any official method of in vitro drug release study. So evaluation of the prepared chewing gums is one of the major challenges.

\section{REFERENCES}

Al-haboubi, M., Zoitopoulos, L., Beighton, D., Gallagher, J. (2010). Gum-chewing for the Prevention of Oral Diseases in Older People. Abstract available at: Website [Accessed on: 02-012012]

Andersen, T., Gram-Hansen, M., Pedersen, M., Rassing, M.R. (1990). Chewing Gum as a Drug Delivery System for Nystatin Influence of Solubilising Agents Upon the Release of Water Insoluble Drugs. Drug Development and Industrial Pharmacy. 16(13): 1985-1994 DOI

Athanikar, N.K., Gubler, S.A. (2001). Process for manufacturing a pharmaceutical chewing gum. US Patent 6,322,828.

Baker, J.R., Bezance, J.B., Zellaby, E., Aggleton, J.P. (2004). Chewing gum can produce context-dependent effects upon memory. Appetite. 43: 207-210. DOI PMid:15458807

Bastian, H.L., Rindum, J., Lindeberg, H. (2004). A doubledummy, double-blind, placebo-controlled phase III study comparing the efficacy and efficiency of miconazole chewing gum with a known drug (Brentan gel) and a placebo in patients with oral candidosis. Oral Surg Oral Med Oral Pathol Oral Radiol Endod. 98(4):423-8. DOI PMid:15472657

Batra, A., Klingler, K., Landfeldt, B., Friedrich, H.M., Westin, A., Danielsson, T. (2005). Smoking reduction treatment with 4-mg nicotine gum: a double-blind, randomized, placebo-controlled study. Clin Pharmacol Ther, 78: 689-696. DOI

Bhise, K.S., Jahagirdar, S. (2005). Medicated chewing gum: a review. Indian J Pharm Educ. 39(3): 139-146.

Bousquet, E., Tirendi, S., Bonina, F.P., Montenegro, L., Bianchi, A., Ciampini, N. (1992). Bioavailability of two formulations of acetylsalicylic acid gums. Pharmazie. 47(8):607-9. PMid:1438512

Christrup, L.L., Rasmussen, S.N., Rassing, M.R. (1988). Chewing gum as a drug delivery system. Farmaci. Sci Ed. 16: 44-47.

Christrup, L.L., Rassing, M.R. (1988). Chewing gum as a drug delivery system: influence of the formulation upon the rate of release of salicylamide. Farmaci Sci Ed. 16: 1-5.

European Directorate for the Quality of Medicines, Council of Europe, European Pharmacopoeia (2000). Suppl. General Chapter 2.9.25: Chewing Gum, Medicated Release from. 3rd Ed. Strasbourg, France; European Directorate for the Quality of Medicines, Council of Europe. pp. 104.

Gajendran, J., Kraemer, J., Knudsen, S.R. (2008). Product Performance Test for Medicated Chewing Gums. Pharmacopeial Forum 34(3): 843-847.

Heema, N., Stuti, G. (2010). Medicated Chewing Gums - Updated Review. International Journal of Pharmaceutical Research and Development. 2(8):66-76.

Hirano, Y., Obata, T., Kashikura, K., Nonaka, H., Tachibana, A., Ikehira, H., et al. (2008). Effects of chewing in working memory processing. Neuroscience Letters. 436: 189-192. DOI PMid:18403120

Hodoba, D. (1999). Chewing can relieve sleepiness in a night of sleep deprivation. Sleep Res Online. 2(4):101-5. PMid:11382890 
Imfeld, T. (1999). Chewing gum-facts and fiction: a review of gum-chewing and oral health. Crit Rev Oral Biol Med 10(3): 405-419. DOI

Jacobsen, J., Bjerregaard, S., Pedersen, M. (1999). Cyclodextrin inclusion complexes of antimycotics intended to act in the oral cavity--drug supersaturation, toxicity on TR146 cells and release from a delivery system. Eur J Pharm Biopharm. 48(3): 217-24. DOI

Jensen, E.J., Schmidt, E., Pedersen, B., Dahl, R. (1990). Effect of nicotine, silver acetate, and ordinary chewing gum in combination with group counselling on smoking cessation. Thorax. 45:831-834. DOI PMid:2256009 PMCid:462778

Jensen, E.J., Schmidt, E., Pedersen, B., Dahl, R. (1991). The effect of nicotine, silver acetate, and placebo chewing gum on the cessation of smoking. The influence of smoking type and nicotine dependence. Psychopharmacology. 104(4): 1223-1231.

Johnson, A.J., Miles, C. (2008). Chewing gum and context dependent memory. The independent roles of chewing gum and mint flavour. British Journal of Psychology. 99: 293-306. DOI PMid:17651533

Kamimori, G.H., Karyekar, C.S., Otterstetter, R., Cox, D.S., Balkin, T.J., Belenky, G.L., Eddington, N.D. (2002). The rate of absorption and relative bioavailability of caffeine administered in chewing gum versus capsules to normal healthy volunteers. International Journal of Pharmaceutics. 234: 159-167. DOI

Keizo, M., Fumio, Y. (1976). Process for the preparation of chewing gum.US Patent $4,000,321$.

Kvist, C., Andersson, S.B., Fors, S., Wennergren, B., Berglund, J. (1999). Apparatus for studying in vitro drug release from medicated chewing gums. Int J Pharm. 189(1):57-65. DOI

Malcolm, R., Currey, H.S., Mitchell, M.A., Keil, J.E. (1986). Silver acetate gum as a deterrent to smoking. Chest. 90(1):107-11. DOI PMid:3522114

Mehta, F., Keservani, R.K., Karthikeyan, C., Trivedi, P. (2010). Chewing gum as a drug delivery system. Archives of Applied Science Research. 2 (2): 79-99.

Moore, M., Hasler-Nguyen, N., Saroea, G. (2008). In vitro tooth whitening effect of two medicated chewing gums compared to a whitening gum and saliva. BMC Oral Health. 8:23. DOI PMid:18694488 PMCid:2527295

Onyper, S.V., Carr, T.L., Farrar, J.S., Floyd, B.R. (2011). Cognitive advantages of chewing gum. Now you see them, now you don't. Appetite. 57: 321-328. DOI PMid:21645566

Pedersen, M., Rassing, M.R. (1990a). Miconazole chewing gum as a drug delivery system test of release promoting additives. Drug Dev Ind Pharm. 16 (1): 55-74. DOI

Pedersen, M., Rassing, M.R. (1990b). Miconazole Chewing Gum as a Drug Delivery System Application of Solid Dispersion Technique and Lecithin. Drug Development and Industrial Pharmacy. 16(13): 2015-2030. DOI

Pedersen, M., Rassing, M.R. (1991). Miconazole chewing gum as a drug delivery system test of release promoting additives. Drug Development and Industrial Pharmacy. 17(3): 411-420. DOI
Peters, M.J., Morgan, L.C. (2002). The pharmacotherapy of smoking cessation. Med J Aust. 176:486-490. PMid:12065013

Rassing, M.R. Specialized oral mucosal drug delivery systems: Chewing gums. In: Rathbone, M.J. (Ed.), Oral Muccosal Drug Delivery, Marcel Dekker, New York, 1996; 319-57.

Rindum, J., Hoimstrup, P., Pederson, M., Masing, M., Stoltze, K. (1993). Miconazole chewing gum for treatment of chronic oral candidosis. Scand J Dent Res. 101:386-390. PMid:8290882

Sakamoto, K., Nakata, H., Kakigi, R. (2009). The effect of mastication on human cognitive processing. A study using eventrelated potentials. Clinical Neurophysiology. 120: 41-50. DOI PMid:19026594

Scholey, A., Haskell, C., Robertson, B., Kennedy, D., Milner, A., Wetherell, M. (2009). Chewing gum alleviates negative mood and reduces cortisol during acute laboratory psychological stress. Physiology and Behavior. 97: 304-312. DOI

Seibel, K., Schaffler, K., Reitmeir, P., Golly, I. (2002). A randomised, placebo-controlled study comparing two formulations of dimenhydrinate with respect to efficacy in motion sickness and sedation. Arzneimittelforschung. 52(7):529-36. PMid:12189776

Shojaei, A.H. (1998). Buccal Mucosa As A Route For Systemic Drug Delivery: A Review. J Pharm Pharmaceut Sci. 1 (1):15-30. PMid:10942969

Skofitsch, G., Lembeck, F. (1983). Serum levels of dimenhydrinate. Determination by HPLC with UV detection after intake of dimenhydrinate in a coated chewing gum dragee. Arzneimittelforschung. 33(12): 1674-6. PMid:6686772

Smith, A. (2010). Effects of chewing gum on cognitive function, mood and physiology in stressed and non-stressed volunteers. Nutritional Neuroscience. 13(1): 7-16. DOI PMid:20132649

Surana, A.S. (2010). Chewing gum: a friendly oral mucosal drug delivery system. International Journal of Pharmaceutical Sciences Review and Research. 4(2): 68-71.

Tucha, L., Simpson, W. (2011). The role of time on task performance in modifying the effects of gum chewing on attention. Appetite. 56(2): 299-301. DOI PMid:21192998

Tucha, O., Mecklinger, L., Maier, K., Hammerl, M., Lange, K.W. (2004). Chewing gum differentially affects aspects of attention in healthy subjects. Appetite. 42: 327-329. DOI PMid:15183924

Uhari, M., Kontiokari, T., Niemelä, M. (1998). A novel use of xylitol sugar in preventing acute otitis media. Pediatrics. 102(4 Pt 1): 879-84. DOI PMid:9755259

Wilkinson, L., Scholey, A., Wesnes, K. (2002). Chewing gum selectively improves aspects of memory in healthy volunteers. Appetite. 38: 235-236. DOI PMid:12071690

Zoladz, P.R., Raudenbush, B. (2005). Cognitive enhancement through stimulation of the chemical senses. North American Journal of Psychology. 7: 125-138.

Zyck, D.J., Greenberg, M.J., Barkalow, D.G., Marske, S.W., Schnell, P.G., Mazzone, P. (2003). Method of making coated chewing gum products containing various antacids. US Patent $6,645,535$. 